\title{
String test
}

\author{
Yoshiro Hadano
}

Department of General Internal Medicine and Infectious Diseases, Rakuwakai Otowa Hospital, Kyoto, Japan

\section{Correspondence to} Dr Yoshiro Hadano, hatayoshiyoshi@gmail.com
To cite: Hadano Y. BMJ Case Rep Published online: [please include Day Month Year] doi:10.1136/bcr-2012008328

\section{DESCRIPTION}

An 82-year-old Japanese woman with duodenum papilla cancer was admitted with a 3-day history of fever, chills and nausea. A contrast-enhanced CT scan showed ring-enhanced and multiloculated lowdensity area in her liver and suspected pyogenic liver abscess (figure 1).

Drainage of the liver abscess was performed and Gram's staining of the abscess revealed Gram-negative bacilli with capsule formation. Blood cultures and abscess cultures grew Klebsiella pneumoniae. Growing colonies from the liver abscess on blood agar were shiny, cream-coloured, and the string test was positive $(>5 \mathrm{~mm}$ string; figure 2). The patient was treated with cefepime for 2 weeks and switched to oral amoxicillin/clavulanate for an additional 4 weeks. No evidence of relapse of the infection was noted at the 6-month follow-up.

Community-acquired $K$ pneumoniae liver abscess sometimes causes metastatic region such as ocular or central nervous system, and hypermucoviscous phenotype of $K$ pneumoniae is associated with hypervirulence. The presence of capsular serotype $\mathrm{K} 1$, and to a lesser extent $\mathrm{K} 2$, appears to play a

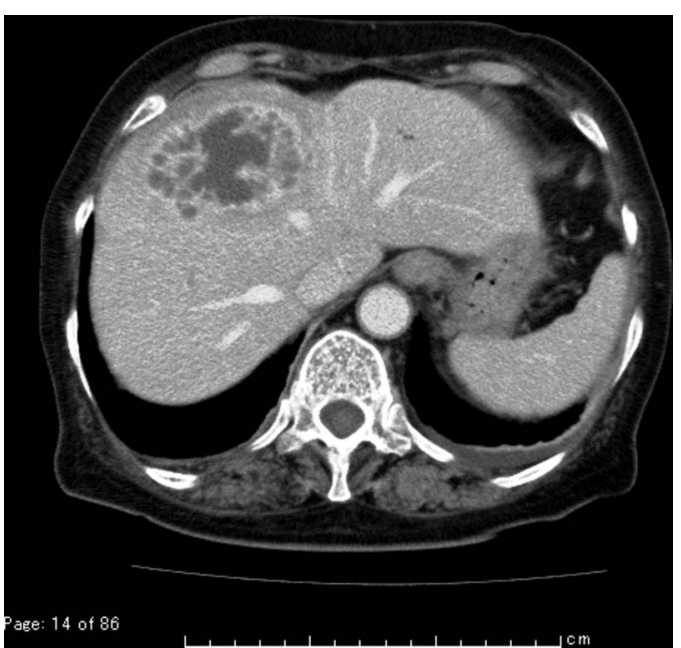

Figure 1 Constrast-enhanced CT scan showing findings suggestive of liver abscess.

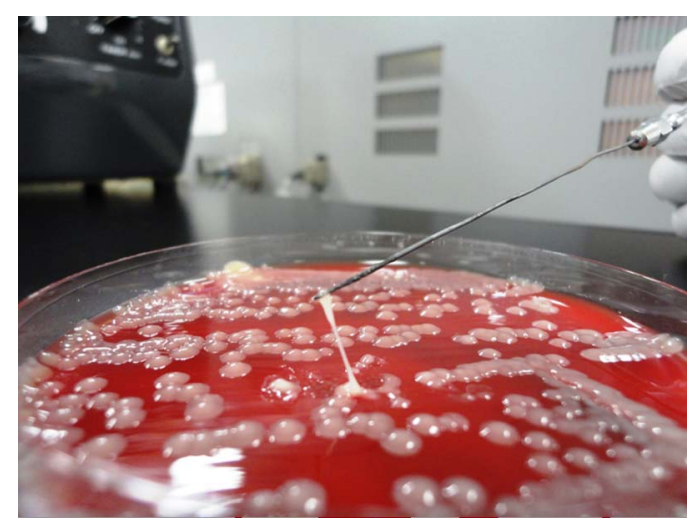

Figure 2 Demonstrating the string test.

role in the virulence of this organism, ${ }^{12}$ and it is easy and very useful to identify the hypervirulence type of $K$ pneumoniae by a string test in the community hospital's laboratory. ${ }^{1}$

\section{Learning points}

- Hypermucoviscous phenotype of Klebsiella pneumoniae is associated with hypervirulence.

- It is easily identified by a string test in the community hospital's laboratory without Caspar serotyping system.

Competing interests None.

Patient consent Obtained.

Provenance and peer review Not commissioned; externally peer reviewed.

\section{REFERENCES}

1 Fang CT, Chuang YP, Shun CT, et al. A novel virulence gene in Klebsiella pneumoniae strains causing primary liver abscess and septic metastatic complications. J Exp Med 2004;199:697-705

2 Fang CT, Lai SY, Yi WC, et al. Klebsiella pneumonia central nervous system complications from pyogenic liver abscess. Clin Infect Dis 2007;45:284-93.

Copyright 2013 BMJ Publishing Group. All rights reserved. For permission to reuse any of this content visit http://group.bmj.com/group/rights-licensing/permissions.

BMJ Case Report Fellows may re-use this article for personal use and teaching without any further permission.

Become a Fellow of BMJ Case Reports today and you can:

- Submit as many cases as you like

- Enjoy fast sympathetic peer review and rapid publication of accepted articles

- Access all the published articles

- Re-use any of the published material for personal use and teaching without further permission

For information on Institutional Fellowships contact consortiasales@bmjgroup.com

Visit casereports.bmj.com for more articles like this and to become a Fellow 